\title{
Pulmonary Hypertension and Neurofibromatosis Type 1: A Case Report with the Revision of Literature
}

\author{
Silvia Garibaldi and Walter Serra* \\ Department of Cardiology, Parma University Hospital, Parma, Italy
}

Submission: August 16, 2019; Published: August 27, 2019

*Corresponding author: W Serra, Department of Cardiology, Parma University Hospital, Parma, Italy

\begin{abstract}
Neurofibromatosis Type 1 (NF1) is an autosomal dominant genetic disorder caused by mutations of the NF1 gene that can lead to the development of benign neurofibroma-like tumours and Malignant Peripheral Nerve Sheath Tumours (MPNST). Pulmonary Arterial Hypertension (PAH) is a rare but severe complication associated with NF1 (PAH-NF). PH-NF1 is classified as group 5 PH, defined as "PH with unclear and/or multifactorial mechanisms", because the mechanisms of PH remain poorly understood. A better understanding of the genetic and molecular mechanisms underlying the disease may require new ways to develop specific therapies. We present the clinical outcomes of a 51-year old female previously diagnosed with NF1, who presented with progressively worsening dyspnea.
\end{abstract}

Keywords: Neurofibromatosis type 1; Pulmonary arterial hypertension; malignant peripheral nerve sheath tumours

Abbreviations: PAH: Pulmonary Arterial Hypertension; NF1: Neurofibromatosis-1; MPNST: Malignant Peripheral Nerve Sheath Tumors; PISA: Proximal Isovelocity Surface Area; ACTPO: Pulmonary Outflow Acceleration Time; TAPSE: Tricusoid Annular Plane Systolic Excursion; PEEP: Positive End-Expiratory Pressure; FFCCS: French Federation of Cancer Centers Sarcoma Group

\section{Introduction}

Neurofibromatosis -1 is an autosomal dominant genetic disorder caused by mutations of the NF1 gene, identified in 1990, which is located at chromosome 17q11.2 [1] and comprises 60 exons. It encodes a cytoplasmic protein named neurofibromin that have a role of tumor suppressor. The incidence of the disease is 1 in 2500-3000 individuals [2,3] The disease is inherited in about $50 \%$ of cases, the rest $50 \%$ are due to de novo mutations [3].

The inactivation of the gene can lead to the development of benign neurofibroma-like tumours and malignant peripheral nerve sheath tumours [4]. Moreover, lung disease, especially Pulmonary Hypertension (PH) may occurs.

PH associated with NF1 (PH-NF1) is a rare but severe complication of NF1 and is classified as Group $5 \mathrm{PH}$, defined as "PH with unclear and/or multifactorial mechanisms" [5].

\section{Case Report}

We present a case of 51-year-old woman that was referred to our hospital due to onset of dyspnea and an anasarca tic state. She also complains of constipation and abdominal pain for a few days. Her previous history revealed chronic obstructive pulmonary disease, severe obesity and past diagnosis of NF.
The patient underwent to thoracic and abdominal Computer Tomography that showed massive and expansive abdominal mass $(25 \times 21 \mathrm{~cm})$ with secondary dislocation of the nearby organs (Figure 1). Eco-guided biopsy allowed the diagnosis of Malignant Peripheral Nerve Sheath Tumors (MPNST), G3 according to FFCCS, compatible with the already known basic pathology.

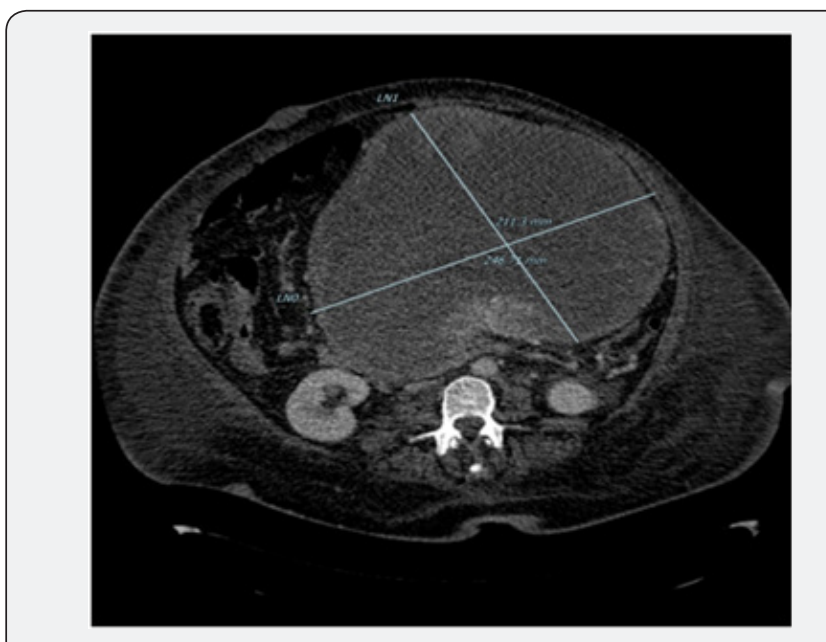

Figure 1: Abdominal mass $(25 \times 21 \mathrm{~cm})$ with secondary dislocation of the nearby organs. 
An echocardiography showed a slight reduction of systolic function of the left ventricle with paradox movement of the interventricular septum, dilated and hypokinetic right ventricle, Actpo $65 \mathrm{msc}$, severe tricuspid regurgitation (PISA radius $>0.9 \mathrm{~cm}$ ) with a right ventricular-right atrial gradient of about $80 \mathrm{mmHg}$ indicative of severe pulmonary hypertension (Figure 2, Panel A \& B).

\section{A}

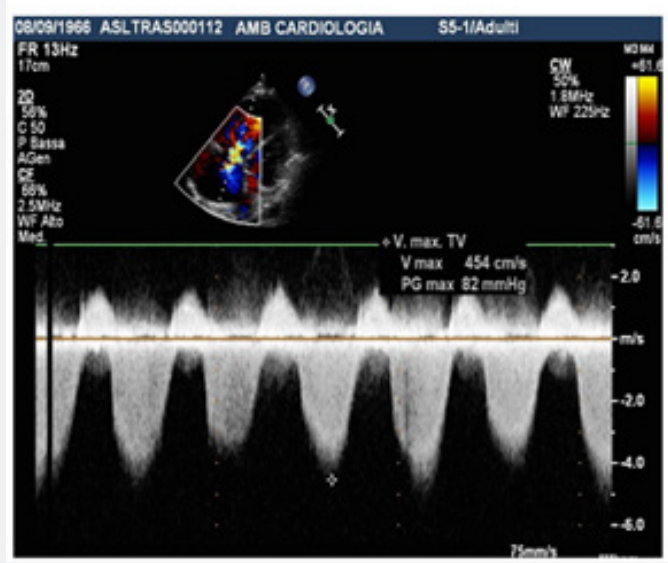

B

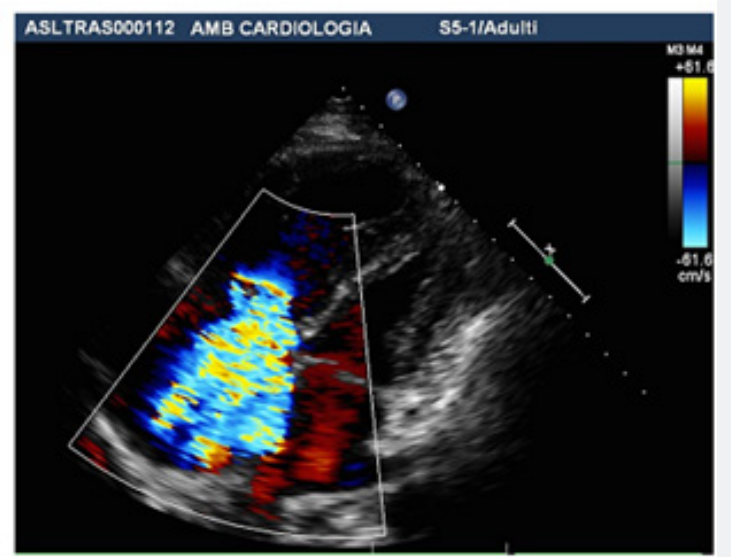

Figure 2: Echocardiography images indicative of severe pulmonary hypertension.

Panel A: Right Ventricular-right atriale gradient of about $80 \mathrm{~mm} \mathrm{Hg}$. Panel B: severe tricuspidal regurgitation.

In the following days, the patient developed severe hypotension associated with respiratory failure treated with dobutamine and prostanoid therapy cycle in association with life support measures (assisted ventilation with low PEEP, diuretics and oral anticoagulants) with subsequent hemodynamic stabilization. An echocardiography performed few days later, we observed an improvement of right ventricular function (TAPSE from 12 to 15.7), reduction of right ventricular volume and of paradoxical movement of interventricular septum, but the degree of pulmonary hypertension remains the same.

After an initial clinical improvement thanks to the pharmacological management, the patient developed a rapid deterioration of the clinical status with fever and hypotension, non-responsive to vasoconstrictor agent. She died for a septic shock.

\section{Results}

In our single experience, a benefit of IV prostanoid therapy has been demonstrated. The development of pre-capillary IP belongs to an NF1 is a rare condition that it must however be suspected in present of dyspnea and investigated by an approach of multimodal imaging.

\section{Discussion}

On data, only 31 cases of precapillary IP associated with NF1 are been described [6]. PH-NF1 was characterized by a female predominance, an advanced age at diagnosis, an association with parenchymal lung disease in two third of cases and poor longterm prognosis [6]. At the moment, there is no data available on the efficacy of specific treatment in PH-NF1 patients [6].
The few and isolated cases reported in the literature report a poor response to specific oral therapy. PH-NF1 is classified as group $5 \mathrm{PH}$, defined as "PH with unclear and/or multifactorial mechanisms" [5], because the mechanisms of PH remain poorly understood. Indeed, it may include different mechanisms such as lung parenchymal destruction, respiratory insufficiency secondary to restriction caused by skeletal abnormalities, left heart disease, but also pulmonary vascular remodeling of the pulmonary arteries and veins [6]. A better understanding of the genetic and molecular mechanisms underlying the disease may require new ways to develop specific therapies.

\section{References}

1. Rasmussen SA, Friedman JM (2000) NF1 gene and neurofibromatosis 1. Am J Epidemiology 151(1): 33-40.

2. Lammert M, Friedman JM, Kluwe L, Mautner VF (2005) Prevalence of neurofibromatosis 1 in German children at elementary school enrollment. Arch Dermatol 141(1): 71-74.

3. Evans DG, Howard E, Giblin C, Clancy T, Spencer H, et al. (2010) Birth incidence and prevalence of tumor-prone syndromes: estimates from a UK family genetic register service. Am J Med Genet A 152A(2): 327332.

4. Sørensen SA, Mulvihill J, Nielsen A (1986) Long-term follow-up of von Recklinghausen neurofibromatosis. Survival and malignant neoplasms. N Engl J Med 314(16): 1010-1015.

5. Galiè N, Humbert M, Vachiery JL, Gibbs S, Lang I, et al. (2015) 2015 ESC/ERS Guidelines for the diagnosis and treatment of pulmonary hypertension. Eur Respir J 46(4): 903-975.

6. Jutant EM, Girerd B, Jaïs X, Savale L, O'Connell C, et al. (2018) Pulmonary hypertension associated with neurofibromatosis type 1. Eur Respir Rev 27(149): 180053. 
This work is licensed under Creative

Commons Attribution 4.0 License

DOI: 10.19080/JOCCT.2019.14.555896

\begin{tabular}{l} 
Your next submission with Juniper Publishers \\
will reach you the below assets \\
- Quality Editorial service \\
- Swift Peer Review \\
- Reprints availability \\
- E-prints Service \\
- Manuscript Podcast for convenient understanding \\
- Global attainment for your research \\
- Manuscript accessibility in different formats \\
( Pdf, E-pub, Full Text, Audio) \\
- Unceasing customer service \\
Track the below URL for one-step submission \\
https://juniperpublishers.com/online-submission.php \\
\hline
\end{tabular}

